\title{
EVALUATION OF STATE OF CULTURAL AND HISTORICAL OBJECTS IN JEKABPILS CITY IN CONTEXT OF SUSTAINABLE DEVELOPMENT
}

Anda Jankava ${ }^{1}$, Dr.oec.; Aina Palabinska ${ }^{2}$, Mg.oec., Sintija Pastare ${ }^{3}$, Mg.sc.ing.

1, 2, 3 Department of Land Management and Geodesy, Faculty of Environment and Civil Engineering, Latvia University of Life Sciences and Technologies

\begin{abstract}
Cultural and historical objects are an important part of our history bringing different evidence about the history of the nation. Dealing with the problems of sustainable development of the territories, it is essential to ensure sustainability of these objects to be able to evaluate them also in the future. In the Republic of Latvia, the aims and priorities of long-term sustainability are included in the Strategy of Spatial Development, where one of the three main objectives is defined - to ensure maintenance of Latvian originality, which includes various nature, cultural heritance and unique landscapes. Jekabpils is one of the cities of the Republic of Latvia, where there is a wide range of cultural and historical objects; they are mainly living houses and buildings of social significance having historical importance. Nevertheless, their condition is very different. The aim of the present article is to evaluate the condition and importance of the cultural and historical objects for promoting sustainable development of the territory of Jekabpils city. Within the range of the research, tracing and visual evaluation of the physical condition of the cultural and historical objects has been carried out according to the criteria suggested by the authors. Identity of the cultural and historical objects has also been determined. It has been stated that in general the condition of the cultural and historical objects is satisfactory and even good; still for about one fourth of these objects the physical condition is not satisfactory what often creates an impression of a degraded territory. Most part of these are living houses that are the property of physical persons.
\end{abstract}

Key words: cultural heritage, cultural and historical objects, sustainable development, land degradation.

JEL code: Q56; Q01; P25

\section{Introduction}

Cultural and historical objects are an important part of our history bringing different evidences about the rich history of the nation. Due to this, it is necessary to ensure sustainable development of these objects to be able to evaluate them proudly also in the future. Speaking about development of the territories, this aspect is one of the most important elements, which should be taken into consideration thinking about long-term planning. Sustainable development envisages that for the present and future generations qualitative environment and balanced economic development should be ensured. Observing of the principle of sustainability is the base for rational usage of natural, human and also material resources, maintenance and development of the natural and cultural heritage. The concept of sustainable development has been defined in the UN Global Commission on Environment and Development report "Our Common Future" (also known as the Bruntland Commission Report, 1987) and is widely used internationally since 1992 at the UN Environment and Development Conference in Rio de Janeiro. Sustainable development is described as "a development that meets the needs of today without compromising the needs of future generations." (Ilgtspejiga attistiba, s.a.).In 2002, celebrating the decade of the Rio de Janeiro conference a UN conference on sustainable development was held in Johannesburg, the Republic of South Africa, that is called "Rio+10". In this conference, the conception of sustainable development was developed, which determined that sustainable development is implemented in three mutually related dimensions: in the sphere of environment, economics and the social aspect (Drexhage, 2010).

Also in the Republic of Latvia since regaining of the independence (in 1990) much has been done in the development of the strategy of sustainable development. Involvement in implementation of sustainable development was a factor that was necessary for the Republic of 
Latvia to join the European Union that officially took place in 2004. In the above mentioned conference of Rio de Janeiro, Latvia participated with a report "Latvian National Report RIO+10", which characterises the environment, social and economic situation in the country. Within the conference "Rio+10", based on the principles accepted in the Rio de Janeiro Declaration, also the "Sustainable Development Basic Statements of Latvia" (Latvijas Nacionalais zinojums..., 2012) have been developed. In turn, thinking about the future, the UN in 2015 adopted a new international programme "Transforming our World: the 2030 Agenda for Sustainable Development" or the so called Agenda 2030, in which 17 sustainable development aims with 169 sub-aims have been stated (Transforming our world..., 2015).

In the Republic of Latvia, the most important document with the long-term development aims and priorities is the Latvian Sustainable Development Strategy or "Latvia 2030". The Strategy is included in the Spatial Development Strategy, where the three main objectives are defined, one of them - to ensure maintenance of Latvian originality, which includes diverse nature, cultural heritance and unique landscapes (Valdmane, 2014). It is clearly seen that in these documents cultural and historical values are of great importance in promotion of sustainable development.

The legal base of the sustainable development strategy in Latvia is formed of several laws of the Republic of Latvia: "On Local Municipalities", "Law on Development Planning", "Law on Territorial Development Planning" and other normative enactments. The aim of the Land Management Law adopted at the end of 2014 in Zemgale also is to promote sustainable usage and protection of land. Land degradation issues are especially underlined in the law. In the Article 3 of the law, it is determined that planning usage of land the local municipality envisages in the territorial planning documents effective management of natural resources and sustainable development. Considering the above mentioned, it can be concluded that an important element in ensuring sustainable development is the ability to evaluate the usefulness and necessity of maintaining a definite object so promoting either destroying or maintaining the degraded objects. It is especially important in planning the territories in the cities, where next to the new town planning objects there are also different cultural and historical objects that have an important meaning in the history of every city and they often determine the further development of the city. Due to different reasons, this historical evidence is not always well maintained and sometimes is irreversibly subjected to degradation, so the land, on which these objects are located, is also degraded.

The cultural and historical heritage is the main treasure of a city that improves density of population and promotes economic development. In general, the future to a great extent depends upon correct and efficient management of different resources; therefore, also maintenance of cultural and historical objects has become an important strategy in promotion of sustainable development of the city environment. The concepts "cultural and historical heritage" and "sustainable development" are today closely related. Relating them makes it possible to relate the past, present and future better trying to achieve objective balance in the management of the whole territory of the city. In order to ensure sustainable development of the city, the balance between the wish to develop the city, to maintain the existing in it environment and cultural history that improves the quality of life of the inhabitants in the city should be observed, at the same time giving invaluable value and investment in the future (Abdel Kader, 2011).

In order to state the rank of the cultural and historical objects in the cultural and historical heritage, a scheme was developed (Fig. 1). In the European Council general convention "Council of Europe Framework Convention on the Value of Cultural Heritage for Society", the cultural heritage 
is formulated as follows: "Cultural heritage is a group of resources inherited from the past which people identify, independently of ownership, as a reflection and expression of their constantly evolving values, beliefs, knowledge and traditions. It includes all aspects of the environment resulting from the interaction between people and places trough time" (Council of Europe..., 2005).It is split in two groups- material and non-material heritage, but irrespective of which group it belongs, it is total treasure that is gained from the previous generations and should be passed over to the future generations. The concept "cultural and historical heritage" is mentioned also in the law of the Republic of Latvia (further in the text LR) "On Protection of Cultural Monuments" in the Article 1 "Cultural monuments are a part of the cultural and historical heritage". So, it can be concluded that cultural monuments fall into the group of the material heritage, which, in turn, is divided into movable and immovable cultural monuments (Par kulturas piemineklu..., 1992). Nevertheless, in the above mentioned law the term "cultural and historical object", which is explained as "cultural and historical buildings of any kind" in the Regulations No. 1620 "Regulations on classification of buildings" of the LR Cabinet of Ministers of 22 December2009, is not mentioned (Noteikumi par buvju..., 2009).

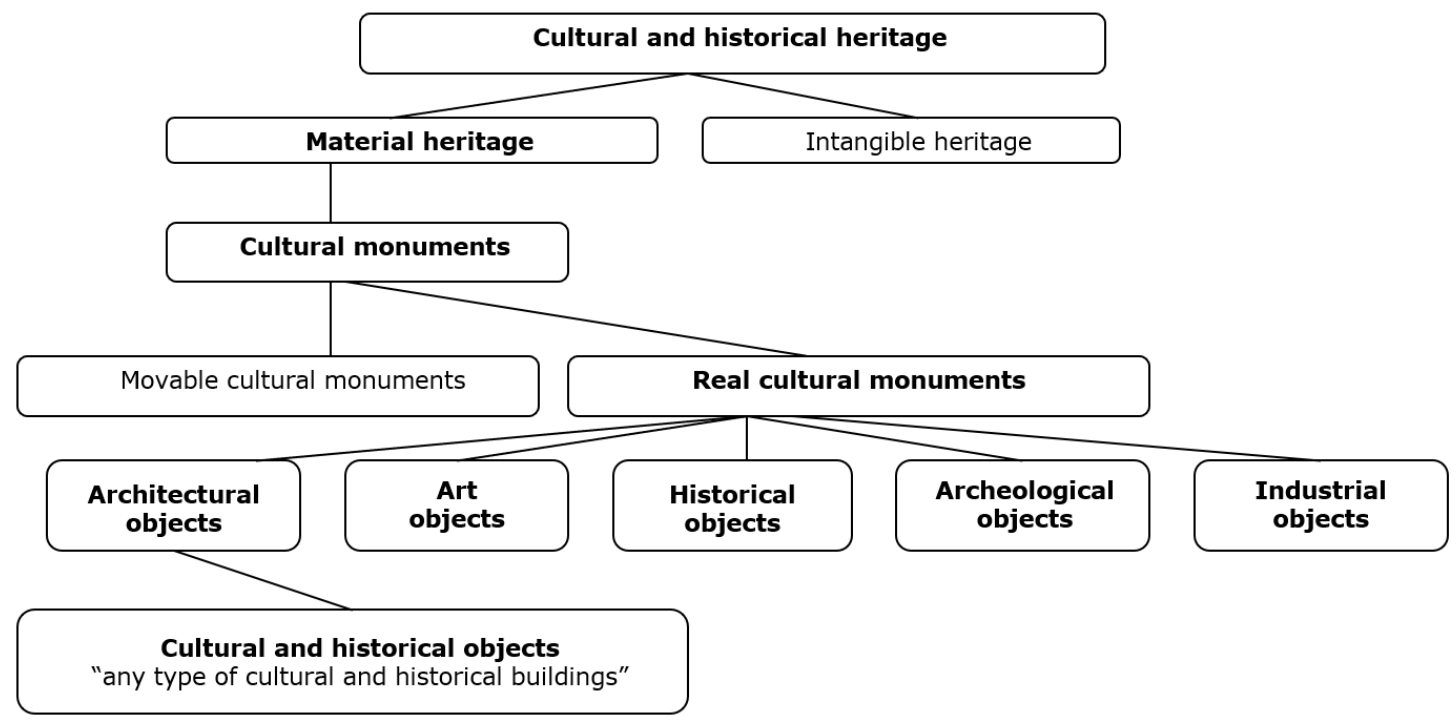

Source: author's calculations based on law "On Protection of Cultural Monuments" and Regulations No. 1620 "Regulations on classification of buildings" of the LR Cabinet of Ministers

\section{Fig. 1. Classification of cultural and historical heritage}

The aim of the present research is to evaluate the condition of the cultural and historical objects of Jekabpils city in context of sustainable development. The object of the research is cultural and historical objects (buildings) in Jekabpils city. The subject of the research is evaluation of the condition of these objects. For this reason, information is summarised about all buildings that are included in the list of protected cultural monuments in Jekabpils city: name, address, cadastre number, status of the owner. These objects were also inspected, visually evaluated and fixed in photos.

Jekabpils is one of the nine cities in the Republic of Latvia with a wide range of cultural and historical values. The city is located in the Southeast of Latvia, in the point of intersection of important railways and motorised highways that connect Latvia with Russia and Belarus. The city is crossed by such main motorways as A6 Riga - Daugavpils - Kraslava - the border with Belarus (Paternieki), A12 Jekabpils - Rezekne - Ludza - the border with Russia (Terehova) and railway 
lines of strategical importance: Riga - Daugavpils, Riga - Rezekne, Krustpils - Jelgava - Ventspils (the latter is used only for freight transportation).

Jekabpils city was historically established in 1962 by joining two different cities (Jekabpils and Krustpils), which were located on both banks of the Latvian fateful river the Daugava. The city is very rich in cultural and historical values created by different historical aspects, natural values as well as prominent personalities (Strategiskais ietekmes uz..., 2012).

In the territory of Jekabpils city, there are cultural and historical monuments of local as well as national meaning. The point "Jekabpils" of the Struve geodesic circle, which is included also in the UNESCO World Heritage List, should be mentioned. "Jekabpils city historical centre", which is divided in two parts marking the historical cities and is maintained from the 14th century, should be mentioned as one of the main town planning monuments. In the cultural and historical centre, there are the historical streets of the city on both banks of the river Daugava with their historical buildings. These are mainly one and two storied wooden buildings from the 19th century and brick houses with luxurious facades built at the end of the 19th century and the beginning of the 20th century, their total amount is close to three hundred.

To evaluate the condition of these cultural and historical objects and the possibilities for their maintenance, within the research all historical buildings that are included in the above mentioned list of cultural monuments as well as the buildings, which are not mentioned as independent objects in this list, but are within the borders of the city historical centre, were inspected. One of the authors of the present article, who is a certified landscape architect, visually evaluated the present condition of the buildings using the categories: "very good", "good", "satisfactory", "bad", "very bad" in accordance with own developed criteria characterising the buildings and their environment (Table 1).

Table 1

Criteria for visual evaluation of condition of cultural and historical objects

\begin{tabular}{|c|c|c|c|c|}
\hline $\begin{array}{l}\text { Very good } \\
\text { condition }\end{array}$ & Good condition & $\begin{array}{l}\text { Satisfactory } \\
\text { condition }\end{array}$ & Bad condition & $\begin{array}{l}\text { Very bad } \\
\text { condition }\end{array}$ \\
\hline $\begin{array}{l}\text { - Restored } \\
\text { building } \\
\text { - In visually good } \\
\text { condition } \\
\text { - Historical value } \\
\text { maintained } \\
\text { - Fits in } \\
\text { surrounding } \\
\text { environment }\end{array}$ & $\begin{array}{l}\text { - Well } \\
\text { maintained } \\
\text { buildings } \\
\text { - Historical } \\
\text { evidences } \\
\text { maintained } \\
\text { - Without } \\
\text { essential } \\
\text { damage }\end{array}$ & $\begin{array}{l}\text { - Moderately } \\
\text { maintained buildings } \\
\text { - Damage of historical } \\
\text { elements can be seen } \\
\text { - Insufficient } \\
\text { management is } \\
\text { evident } \\
\text { - Historical elements } \\
\text { are replaced by } \\
\text { improper materials }\end{array}$ & $\begin{array}{l}\text { - Buildings are not } \\
\text { well maintained } \\
\text { - Traits of } \\
\text { degradation in the } \\
\text { territory } \\
\text { - Maintained } \\
\text { historical values } \\
\text { are damaged }\end{array}$ & $\begin{array}{l}\text { - Buildings are not } \\
\text { used and } \\
\text { managed } \\
\text { - Visually spoil } \\
\text { surrounding } \\
\text { environment } \\
\text { - Territory subject } \\
\text { to degradation }\end{array}$ \\
\hline
\end{tabular}

Source: author's calculations

For maintenance of cultural and historical objects, it is important to know who owns these objects; therefore, in the research using the address and cadastre number, and the State Land Service website www.kadastrs.Iv for all objects the kind of property according to the status of the owner was determined: state property, municipal property, property of a physical person, property of legal person, mixed status joint property and especially marked property of foreigners. In the research, the condition of the cultural and historical objects depending on the owner has been analysed. 


\section{Research results and discussion}

\section{Characterisation of the situation}

The territory of the historical centre of Jekabpils city is included in the list of national town planning monuments with No. 7432. For this monument of town planning only the borders are determined, but its inventory listing the cultural and historical objects and their value has not been performed. Inspecting this territory, there were 299 objects - historical buildings stated and listed. A small number of these buildings that are within the borders of Jekabpils historical centre are included in the list of protected cultural monuments. In this list, there are also several buildings of the city included that are located outside the city historical centre. In total, 21 objects in this list are mentioned as national architectural monuments and 49 objects as architectural monuments of local meaning. The situation is as follows: although the whole territory of the centre has got the status of a town planning monument of national importance, the largest part of the historical centre buildings is not protected as they are not included in the above mentioned list. In order to get a general view on the condition of the cultural and historical objects in the city, all cultural and historical objects in the historical centre of Jekabpils city as well as the objects mentioned in the list of protected cultural and historical monuments that are located outside the historical centre were inspected, listed and evaluated according to the above mentioned criteria. In the research, the following objects are analysed separately:

- cultural and historical objects included in the list of cultural monuments of national meaning - 21;

- cultural and historical objects included in the list of cultural monuments of local meaning - 49;

- objects located in the cultural and historical centre -299.

\section{Analysis of the objects included in the list of cultural and historical monuments}

In compliance with the law "cultural monuments in the Republic of Latvia can be properties of the state, municipalities, other public persons and private persons" (Par kulturas piemineklu...,1992). Analysing the objects included in the list of cultural and historical monuments of national meaning according to their ownership, it can be seen that the largest part of them is a property of physical persons (33\%) and legal persons (33\%). They are mostly living houses owned by physical persons and several household buildings (for instance, a barn, a threshing barn) that have historical importance. In turn, legal entities own several churches and outhouse buildings (barns, sheds, barrack buildings). Two of the objects included in this list (the historical building of the district school and the barn) are owned by the government institutions, but three objects (Krustpils castle and two household buildings) are owned by the local municipality. Inspecting these objects, it can be concluded that the cultural and historical monuments owned by the state and the local municipalities are comparatively well maintained. Also the cultural and historical monuments owned by legal persons (especially the church buildings) are in a good condition except one object - the barrack building, which is in a very bad condition and subject to degradation. In turn, the condition of the objects protected by the state but owned by physical persons is different - mostly in good and satisfactory condition, nevertheless, some buildings are practically not used and are in decay (Fig. 2).

Also the objects in the list of cultural and historical monuments of local meaning, in total 49, are owned mainly by physical persons (40\%) and legal persons (29\%) (Fig. 2). Under the ownership 
of physical persons from these groups there are mainly living houses or living houses with a shop or pharmacy, among them the memorial house, but under the ownership of legal persons - also living houses, several churches, health centres, the bank building and the construction of the former manor. A part of the objects in the list of cultural and historical monuments of local meaning are owned by the local municipalities; they are the building of the historical district county court, the former Abelu and Krustpils village council and board buildings, the former Guard house, some living houses etc. Evaluating the condition of the objects listed in the list of cultural and historical monuments, it can be concluded that in general the situation is seemingly satisfactory, still the fact that a part of the objects are not used or are in a bad condition is not favourable. Besides, these objects that are in a poor condition are owned by physical persons as well as by legal persons and also by the local municipality. Furthermore, several properties owned by the legal persons (4\%) are evaluated even as being in a very bad condition.

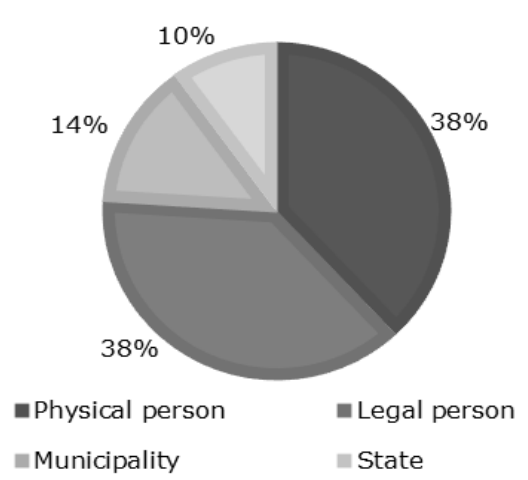

a) national meaning

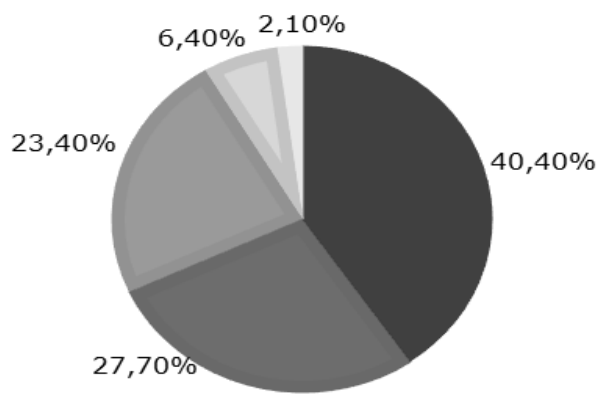

- Psysical person

- Legal person

Municipality

Mixed status shared property

Foreigner

b) local meaning

Source: author's calculations

Fig. 2. Ownership of Jekabpils city cultural and historical objects of national and local meaning

\section{Analysis of the objects located in the territories of the city historical centre}

Researching in the ownership of the buildings located in the historical centre, it has been stated that the most part - 195 or $65.4 \%$ of the buildings are owned by physical persons, 41 buildings or $13.8 \%$ are owned by legal persons and 24 buildings or $8.1 \%$ are owned by local municipalities. Owners of 4 buildings ( $1.3 \%$ ) are persons living abroad. 33 buildings or $11.1 \%$ have a status of joint property, but only one object $(0.3 \%)$ is under the state ownership. This is a building in 1 Pasta Street having a historical name "District school". This building is included in the list of cultural and historical monuments of national meaning. Inspecting the building, it was stated that its visual condition is good (Fig. 3).

Evaluating the condition of the buildings in the territories of the historical centre, it can be concluded that $42 \%$ of the buildings are in a good and very good condition, $31 \%$ of the buildings - in a satisfactory condition. Still, the fourth part of the buildings is in a bad or very bad condition (Fig. 4). The most part of the buildings in bad condition belong to physical persons. At the same time, there are also many buildings owned by physical persons that are in a good and satisfactory condition. Summarising the obtained results, it can be concluded that the most part of the inspected objects in the territories of the historical centre are living houses, the owners of which try to tend their properties properly. Nevertheless, inspecting these objects, it has been stated that 
some of the owners have chosen cheaper materials for repairing their buildings, for instance, replacing the historical windows with plastic ones so reducing the authenticity of these buildings. In such cases the visual condition of the buildings was assessed as satisfactory (Table 1) and, as it can be seen, there are comparatively many cases with satisfactory evaluation, especially the buildings owned by physical persons (Fig. 3).
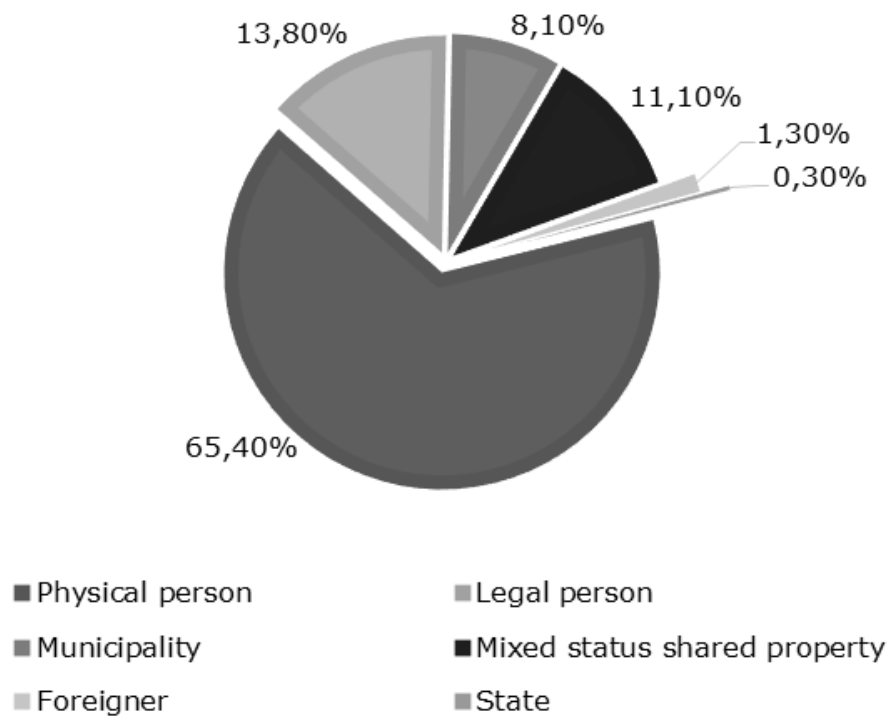

Source: author's calculations

Fig. 3. Proportion of buildings according to ownership in historical centre territories

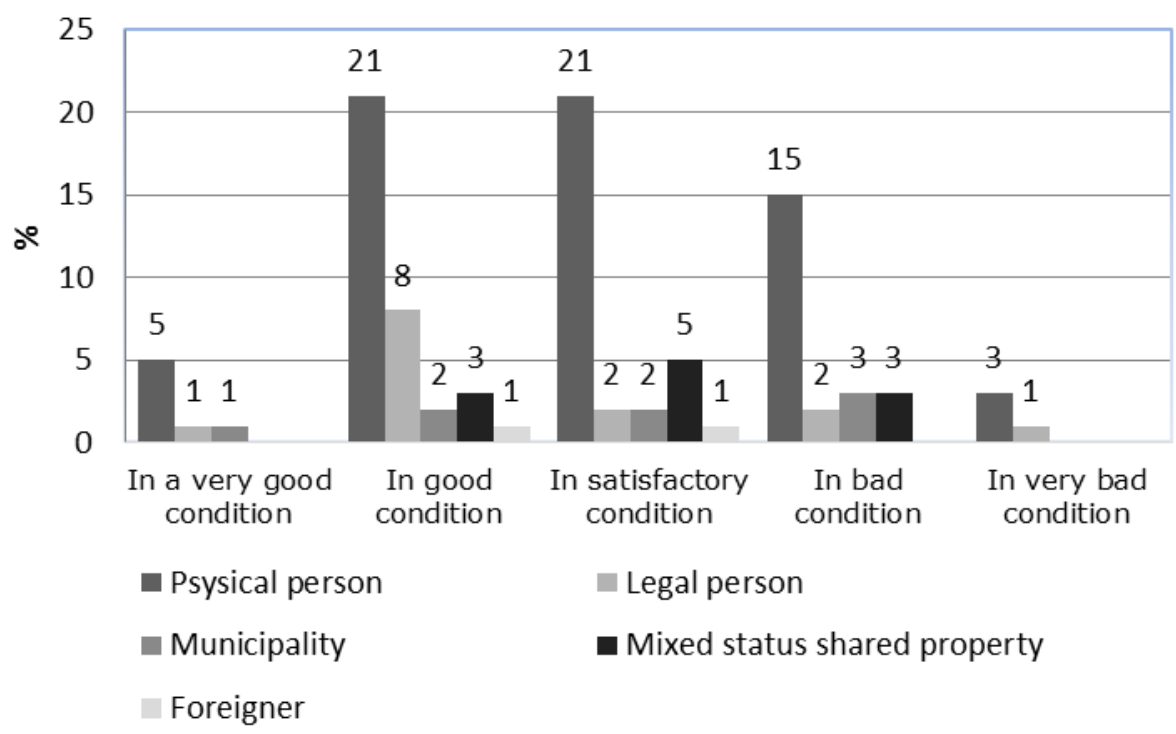

Source: author's calculations

Fig. 4. Evaluation of objects in territories of Jekabpils city historical centres ( $\%)$ according to ownership

As the performed analysis shows, in Jekabpils city there is a wide range of cultural and historical objects that reflect the rich history of the city and are important in promotion of sustainable development. Nevertheless, the physical and visual condition of these objects is different. A large part of the objects, especially in the territories of the historical centres, mainly the living houses owned by physical persons are predominantly in a satisfactory or good condition, still almost one fourth of them are in a bad or even in a very bad condition. Besides, a part of them are included in 
the national level list of cultural and historical monuments as well as in the local level list. Also several buildings that are included in the mentioned lists and are owned by legal entities and the local municipality are in a bad physical condition; these are most often buildings of social significance. Churches are an exception as their condition is good. Although not all of the existing buildings in the territories of the cultural and historical centres are included in the list of cultural and historical monuments, still they all together form a territory that is a cultural and historical monument.

Entering the property rights on immovable property that is considered as a cultural monument in the Land Register, restrictions of the immovable property rights should be marked, so these objects are officially recognised as encumbrance for their owners. In compliance with the law, physical persons and legal persons should ensure that the cultural monuments owned by them are maintained. Maintenance of the cultural monuments owned by the state should be ensured by the persons responsible for them. In the law "On Protection of Cultural Monuments", it has been stated that conservation, maintenance, repair and restoration of the cultural monuments is done by their owners at their own expenses. It should be admitted that not all inhabitants have enough finances for maintaining and repairing of their properties and, moreover, the status of a cultural monument requires different additional provisions and requirements in this work.

Cultural and historical heritage is a value for all inhabitants of the city and its guests; therefore, its management and maintenance are of great importance. Their maintenance invests in economic development and increases the development of international tourism (Karnite, 1999). The local municipality of the particular territory has great importance in maintaining of the cultural and historical heritage and informing of the society about these values. There are also good examples of this in Latvia, for instance, in the city Kuldiga, the council of which has made great investment in gathering information about the cultural and historical values, involving and educating the society achieving good results (Jakabsone, 2010). There are also many examples outside Latvia in the economically developed countries, where the significance of cultural and historical objects is on a much higher level as it is today in Latvia (Karnite, 1999). Nevertheless, also there, in spite of the fact that the society is educated and interested in maintenance of the cultural and historical heritage, still additional stimuli are needed in this sphere (Turlaja, 2011).

\section{Conclusions, proposals, recommendations}

1) In Jekabpils city, there is a wide range of cultural and historical values that are influenced by different historical aspects, the geographical location, natural values and prominent people. Comparatively many cultural and historical objects are included in the list of protected cultural monuments. Jekabpils city centre is listed there as a special cultural monument of national meaning, although the status of a cultural monument is assigned only to separate buildings of this centre.

2) The objects included in the Jekabpils city and local level list of protected cultural monuments are owned mainly by physical and legal persons. Usually these are living houses owned by physical persons. In turn, several churches and household buildings are owned by legal persons. Inspecting these buildings, it has been stated that their present condition is different - in total the condition is satisfactory, but there are well maintained buildings as well as several buildings that degrade the territory. 
3) Also in the territory of "Jekabpils city historical centre" that is included in the list of protected cultural monuments on the national level the most part (more than $65 \%$ ) is occupied by living houses owned by physical persons. Generally, the buildings in the territory of this centre are in a good and satisfactory condition; nevertheless, the fourth part is occupied by buildings in a bad condition.

4) Cultural and historical heritage is a value; its maintenance and information of the society about these values are important aspects in the development of the territories. The local municipality of a particular territory plays an important role in maintenance of cultural and historical heritage and information of the society about these values. In any case, formation of different communes and associations, how to organise consultations, development of guidelines and accessibility as well as information and education of the society should be considered.

\section{References}

1. Abdel Kader,B. (2011) Heritage Rehabilitation in Sustainable Development Policy for a Better Environment Quality in Small Historical Coastal Cities: the Case of Cherchell in Algeria. 2011 International Conference on Green Buildings and Sustainable Cities. Procedia Engineering, No. 21, p. 753-759.

2. Drexhage, J., Deborah, M. (2010) Sustainable Development: From Brundtland to Rio 2012. Paper presented at the High Level Panel on Global Sustainability at its first meeting, 19 September 2010, United Nations Headquarters, New York.

3. Council of Europe Framework Convention on the Value of Cultural Heritage for Society (2005). Retrieved: https://rm.coe.int/CoERMPublicCommonSearchServices/DisplayDCTMContent?documentId=0900 001680083746. Access: 05.02.2018.

4. Ilgtspejiga attistiba: VARAM mājaslapa. (Sustainable Development: home page of Ministry of Environmental Protection and Regional Development of the Republic of Latvia). Retrieved: http://www.varam.gov.Iv/lat/darbibas_veidi/ilgtspejiga_attistiba/. Access: 31.01.2018.

5. Jakabsone, J. (2010) Kulturvesturiska mantojuma saglabasana un attistiba - viena no pilsetu ilgtspejigas attistibas nostadnem. Kuldigas pasvaldibas darbs kulturvesturiska mantojuma saglabasana. RTU zinatnisko rakstu serija: Ilgtspejiga telpiska attistiba, Sejums Nr.1, 99. - 103. Ipp.

6. Karnite, R. (1999) Kulturas sektora tautsaimnieciskais nozimigums. Retrieved: https://www.km.gov.Iv/uploads/ckeditor/files/kultura_timekli/Kult_Sekt_Nozimig_1999.pdf. Access: 05.02.2018.

7. Latvijas Nacionalais zinojums "Rio+10" ANO Ilgtspejigas attistibas konferencei Johannesburga. (2012) LR Ministru kabineta rikojums Nr. 435. Riga. 56 Ipp.

8. Noteikumi par buvju klasifikaciju: MK 2009. gada 22. decembra noteikumi Nr. 1620. Latvijas Vestnesis, Nr. 205, 2009. gada 30. decembri (Regulations on classification of buildings).

9. Par kulturas piemineklu aizsardzibu: LR likums (1992), pienemts 12.02.1992. (On Protection of Cultural Monuments: Law of the Republic of Latvia).

10. Strategiskais ietekmes uz vidi novertejums. Vides parskats. Jekabpils pilsetas ilgtspejigas attistibas strategijai 2014. lïdz 2030. gadam. Jekabpils pilsetas attistibas programmai 2014.-2020. gadam (2012). Jekabpils. 102 Ipp.

11. Transforming our world: the 2030 Agenda for Sustainable Development (2015). Retrieved: https://sustainabledevelopment.un.org/post2015/transformingourworld. Access: 02.02.2018.

12. Turlaja A. (2011) Kulturas mantojuma politika un prakse Lielbritanija. Biedribas "Es Latgalei" pieredzes brauciena apkopojums projekta "Biedribas "Es Latgalei"" un citu NVO kapacitates un lidzdalibas resursu stiprinasana" ietvaros. Biedriba "Es Latgalei".

Retrieved: https://eslatgalei.files.wordpress.com/2011/06/buklets-lejuplc481dei.pdf. Access: 05.02.2018.

13. Valdmane I. (2014) Metodiskie ieteikumi regionala un vieteja limena ilgtspejigas attistibas strategiju izstradei un to vertesanas kartibai. Vides aizsardzibas un regionalas attistibas ministrijas Telpiskas planosanas departamenta Planojumu uzraudzibas nodala. 